\title{
EVALUASI PENERAPAN RENCANA TATA BANGUNAN DAN LINGKUNGAN (RTBL) KAWASAN WISATA PANTAI TELUK PENYU DAN BENTENG PENDEM
}

\author{
Eka Lusiana ${ }^{1)}$, Sylvie Wirawati ${ }^{21}$ \\ 1) Program Studi S1 PWK, Fakultas Teknik, Universitas Tarumanagara, alusiana66@gmail.com \\ 2) Program Studi S1 PWK, Fakultas Teknik, Universitas Tarumanagara, sylvie.wirawati@gmail.com
}

Masuk: 04-02-2020, revisi: 28-02-2020, diterima untuk diterbitkan: 09-05-2020 (doi: 10.24912/stupa.v2i1.7291)

\begin{abstract}
Abstrak
Kawasan wisata Pantai Teluk Penyu dan Benteng Pendem, merupakan dua jenis wisata berbeda yang berada pada satu kawasan, yang terletak di Kecamatan Cilacap Selatan, Kabupaten Cilacap, Provinsi Jawa Tengah. Dokumen Rencana Tata Bangunan dan Lingkungan (RTBL) pada kawasan ini dalam penerapannya terdapat beberapa rencana yang tidak sesuai baik dengan kebutuhan masyarakat dan pengunjung, maupun dengan kebijakannya, yang kemudian akan dibandingkan dengan beberapa faktor-faktor pedoman umum RTBL dan kebutuhan masyarakat sekitar, pedagang/pelaku usaha dan pengunjung. Sehingga penulis akan melakukan Evaluasi Penerapan Rencana Tata Bangunan dan Lingkungan (RTBL) Kawasan wisata Pantai Teluk Penyu dan Benteng Pendem. Adapun tujuan dari penelitian ini yaitu mengevaluasi RTBL Pantai Teluk Penyu dan Benteng Pendem dilihat dari dokumen rencana fisik RTBL, kebijakan atau undang-undang terkait Pedoman RTBL, daya tarik eksisting, dan persepsi dan kepuasan dari sisi pengunjung dan masyarakat/pelaku usaha terhadap fasilitas dan rencana di Pantai Teluk Penyu, dan kesesuaian dengan faktor-faktor pedoman umum RTBL. Untuk mencapai tujuan tersebut maka dilakukan beberapa analisis dengan menggunakan alat analisis seperti deskriptif, diagram kartesisus, dan csi. Sehingga hasil dari analisis yang dilakukan tersebut dapat digunakan untuk menilai bagaimana kesesuaian rencana fisik dari RTBL dengan pedoman umum dan kebutuhan masyarakat.
\end{abstract}

Kata Kunci: pedoman umum rtbl; rencana fisik; rencana tata bangunan dan lingkungan

\begin{abstract}
The Teluk Penyu Beach and Benteng Pendem tourism areas, are two different tours in one area, located in South Cilacap Subdistrict, Cilacap Regency, Central Java. Document of Building and Environmental Planning (RTBL) of the area in its implementation are some compatible plans that will be compared with the general guideline factors of the RTBL and the needs of the community, traders and visitors. So the authors will Evaluate the Implementation of Building and Environmental Planning (RTBL) in the Teluk Penyu Beach and Benteng Pendem tourism area. The purpose of this study is to evaluate the RTBL of the Teluk Penyu Beach and Benteng Pendem viewed from the document physical plan of the RTBL, policies or laws related to the RTBL guidelines, existing attractiveness, and perceptions and satisfaction from the visitors and community side to facilities and plans on the Teluk Penyu Beach, and the suitability to RTBL guiding factors. To achieve these objectives, several analyzes were using analytical tools such as descriptive, cartesian diagrams, and CSI. So the results of the analysis can be used to assess how to the suitability of the physical plan of the RTBL.
\end{abstract}

Keywords: Building and Environmental Planning (RTBL); physical plan; rtbl general guidelines 


\section{PENDAHULUAN}

Indonesia merupakan negara kepulauan dengan berbagai macam pulau yang dapat berpotensi sebagai sektor wisata. Indonesia juga merupakan negara yang memiliki keanekaragaman sumber daya alam, budaya dan berbagai jenis pariwisata yang melimpah. Di Indonesia sendiri terdapat berbagai jenis pariwisata mulai dari wisata alam, peninggalan sejarah, dan berbagai tempat wisata buatan. Salah satu kegiatan pariwisata Pantai yang menarik dengan adanya lagi wisata lain yang berbeda salah satunya berada di Kabupaten Cilacap, Jawa Tengah. Wisata tersebut merupakan wisata Pantai Teluk Penyu dan wisata sejarah Benteng Pendem. Pantai Teluk Penyu merupakan salah satu pantai di Kabupaten Cilacap yang memiliki karakteristik dan potensi yang berbeda dengan daerah lainnya. Di antara obyek wisata pantai yang lain, pantai ini cukup menonjol karena merupakan ikon khas kota Cilacap.

Berdasarkan data dari Dinas Pariwisata Kabupaten Cilacap, obyek wisata Pantai Teluk Penyu juga merupakan penyumbang pendapatan terbesar dari sektor pariwisata bila dibandingkan dengan obyek wisata lainnya yang ada di Cilacap dilihat dari banyaknya jumlah kunjungan wisatawan ke obyek wisata Pantai Teluk Penyu. Jarak Pantai Teluk Penyu dengan pusat kota sangat dekat yaitu kurang lebih $2 \mathrm{~km}$. Pantai ini juga merupakan salah satu akses untuk menyeberang ke Pulau Nusakambangan dengan menggunakan kapal-kapal yang dikelola oleh masyarakat sekitar.

Karena jarak yang sangat dekat dengan pusat kota menjadikan sebagian kawasan wisata ini tidak sesuai dengan fungsinya. Dalam satu area yang sama dengan kawasan wisata bahkan banyak berdiri rumah-rumah warga. Rumah-rumah warga ini berdiri diatas tanah hak milik PT.Pertamina yang juga membangun objek vital negara yaitu Kilang Minyak PT Pertamina (Persero) Refinery Unit (RU) IV Cilacap tepat disebelah bangunan Benteng Pendem.

Munculnya Kilang Minyak PT Pertamina (Persero) Refinery Unit (RU) IV Cilacap tadi sebagai kilang minyak terbesar di Indonesia ini pada tahun 1970-an membuat bangunan wisata Benteng Pendem tidak utuh lagi, atau dalam arti lain sebagian tanah atau lahan Benteng Pendem dibeli oleh pihak pertamina, dan sebagian bangunan Benteng Pendem diatasnya dihancurkan. Bahkan jalan disamping tembok batas Benteng Pendem merupakan akses masuk bagi para pekerja di kilang minyak ini.

Pada tahun 2016 kilang Pertamina ini sempat meledak dan terbakar, hal ini menganggu dan meresahkan bagi pengunjung tempat wisata, terutama pengunjung Benteng Pendem yang letaknya bersebelahan dengan kilang-kilang pertamina tersebut. Didalam kawasan ini juga pernah menjadi tempat latihan militer oleh TNI Banteng Loreng Kesatuan Jawa Tengah. Sebagian tanah pesisir pantai hingga kini juga masih menjadi milik TNI atau yang sekarang disebut KODIM 0703 Cilacap. Para pemilik warung yang mendirikan bangunan warungnya di pinggir pantai atau diatas tanah milik TNI juga membayar iuran kepada pihak TNI setiap tahunnya. Hingga kini posko latihan milih TNI masih ada di kawasan wisata Pantai Teluk Penyu dan Benteng Pendem.

Sesuai dengan Rencana Induk Pengembangan Kepariwisataan Provinsi Jawa Tengah 2012-2027, kawasan wisata ini dijadikan sebagai Kawasan Strategis Pariwisata Provinsi (KSPP) Cilacap, di dukung adanya Rencana Tata Bangunan Lingkungan (RTBL) Pantai Teluk Penyu yang disusun oleh Dinas Cipta Karya dan Tata Ruang dan Badan Pembangunan Daerah Kabupaten Cilacap pada tahun 2012. Namun, meskipun sudah didukung dengan adanya RTBL Pantai Teluk Penyu, sejumlah rencana yang terdapat dalam RTBL tidak sepenuhnya berhasil diterapkan, masih banyak kondisi eksisting yang tidak mendukung untuk terealisasinya rencana tersebut baik dari kondisi lahan ataupun peran dari masyarakat sekitar. Dengan adanya fenomena ini maka penulis tertarik melakukan penelitian untuk mengevaluasi RTBL Kawasan wisata Pantai Teluk Penyu dan Benteng Pendem Kabupaten Cilacap. 


\section{KAJIAN LITERATUR}

\section{Evaluasi}

Evaluasi menurut KBBI (Kamus Besar Bahasa Indonesia) berarti penilaian; hasil. Menurut Charles O. Jones (2009) evaluasi adalah kegiatan yang dapat menyumbangkan pengertian yang besar nilainya dan dapatpula membantu penyempurnaan pelaksanaan kebijakan beserta perkembangannya. Pengertian tersebut menjelaskan bahwa kegiatan evaluasi dapat mengetahui apakah pelaksanaan suatu program sudah sesuai dengan tujuan utama, yang selanjutnya kegiatan evaluasi tersebutdapat menjadi tolak ukur apakah suatu kegiatan atau kebijakan dapat dikatakan layak diteruskan, perlu diperbaiki atau dihentikan/tidak dapat diteruskan. Menurut Peraturan Pemerintah No.39 tahun 2006, evaluasi adalah rangkaian kegiatan membandingkan realisasi masukan (input), keluaran (output), dan hasil (outcome) terhadap rencana dan standar.

\section{Rencana Tata Bangunan dan Lingkungan}

Rencana Tata Bangunan dan Lingkungan (RTBL) menurut Peraturan Menteri Pekerjaan Umum nomor 6 tahun 2007 adalah panduan untuk merancang atau membangun suatu lingkungan/kawasan untuk mengendalikan pemanfaatan ruang yang memuat rencana program bangunan dan lingkungan, rencana umum dan panduan rancangan, rencana investasi, ketentuan pengendalian rencana dan pedoman pengendalian pelaksanaan pengembangan lingkungan/kawasan.

Dokumen Rencana Tata Bangunan dan Lingkungan (RTBL) disusun dengan tujuan sebagi pengendali pembangunan, yaitu mengendalikan penyelenggaraan penataan bangunan dan lingkungan suatu kawasan tertentu.

Prinsip-prinsip utama penyusunan Dokumen RTBL adalah:

- Berorientasi pada aspek kemampuan daya dukung sosial budaya dan lingkungan dari lokasi setempat, bukan pada aspek tuntutan kebutuhan ekonomis semata;

- Melibatkan peran masyarakat pengguna dan/atau pelaku pembangunan (stakeholder) dalam proses penyusunannya untuk menghasilkan kesepakatan dan bersifat mengikat;

- Berdasar pertimbangan efektivitas pemanfaatan ruang yang ada, prediksi kontinuitas pelaksanaan program, dan peluang manfaat yang akan dicapai;

- Mempunyai kejelasan kelembagaan pengelola dan pemantau pelaksanaan program

\section{Acuan Kebijakan}

Berikut ini merupakan landasan hukum atau kebijakan yang dapat dijadikan acuan oleh penulis dalam melakukan penelitian :

Tabel 1. Daftar Kebijakan

\begin{tabular}{lll}
\hline No. & \multicolumn{1}{c}{ Kebijakan } & \multicolumn{3}{c}{ Perihal } \\
\hline 1. & $\begin{array}{l}\text { Perda Provinsi Jawa Tengah nomor } \\
10 \text { tahun } 2012\end{array}$ & $\begin{array}{l}\text { Rencana Induk Pembangunan Kepariwisataan Provinsi } \\
\text { Jawa Tengah tahun 2012-2027 }\end{array}$ \\
\hline 2. & $\begin{array}{l}\text { Perda Kab. Cilacap nomor 9 tahun } \\
2011\end{array}$ & $\begin{array}{l}\text { Rencana Tata Ruang Wilayah Kabupaten Cilacap tahun } \\
2011-2031\end{array}$ \\
\hline 3. & - & $\begin{array}{l}\text { Rencana Pembangungan Jangka Menengah Daerah } \\
\text { (RPJMD) tahun 2017 - 2022 }\end{array}$ \\
\hline 4. & Permen PU nomor 6 tahun 2007 & $\begin{array}{l}\text { Pedoman Umum Rencana Tata Bangunan dan } \\
\text { Lingkungan }\end{array}$ \\
\hline
\end{tabular}

Sumber : Google.com, 2019 


\section{METODE}

Data yang dikumpulkan selama proses penelitian adalah data kondisi fisik eksisting, Rencana Tata Bangunan dan Lingkungan (RTBL) termasuk rencana fisiknya, sejarah kawasan wisata Pantai Teluk Penyu dan Benteng Pendem, Rencana Tata Ruang Wilayah (RTRW) 2011-2031, jumlah pengunjung, dan faktor-faktor pedoman umum RTBL.

Teknik pengumpulan data yang dilakukan dalam penelitian yaitu metode pengumpulan data primer dan metode pengumpulan data sekunder. Untuk metode pengumpulan data primer dilakukan dengan observasi/survei lapangan, wawancara denganpihak terkait dan penyebaran kuesioner. Untuk pengumpulan data sekunder dilakukan dengan dokumentasi dan studi literatur.

Adapun cara pengambilan sample untuk mengetahui jumlah responden yang harus mengisi kuesioner digunakan dengan metode slovin atau sebuah rumus/formula untuk menghitung jumlah sampel minimal apabila perilaku dari sebuah populasi tidak diketahui secara pasti.. Dengan sebagai populasi (N) sebanyak 240.666 yaitu jumlah pengunjung Pantai Teluk Penyu dan Benteng Pendem tahun 2017 dan ditentukan bahwa batas toleransi kesalahan pengambilan sampel dalam penelitian sebesar $10 \%$.

$$
\mathrm{n}=\frac{\mathrm{N}}{1+\mathrm{Ne}^{2}}
$$

$$
\begin{aligned}
& n=\frac{240.666}{1+240.666 \times 0.10^{2}} \\
& n=99,96=100
\end{aligned}
$$

Keterangan :

$\mathrm{n}$ : Jumlah sample

$\mathrm{N}$ : Jumlah populasi

$\mathrm{E}$ : batas toleransi kesalahan

Untuk analisis yang dilakukan dalam penelitian adalah analisi kondisi eksisting yang terbagi menjadi analisis fisik lingkungan, analisis penerapan rencana, analisis kebijakan, dan analisis persepsi dan preferensi pengunjung.

\section{DISKUSI DAN HASIL}

\section{Analisis Kondisi Eksisting}

\begin{tabular}{|c|c|c|}
\hline Aspek & Fungsi & Kesimpulan \\
\hline \multirow[t]{3}{*}{$\begin{array}{l}\text { Kondisi } \\
\text { Prasarana }\end{array}$} & Jaringan Jalan & $\begin{array}{l}\text { Berdasarkan Peraturan Menteri Pariwisata nomor } 3 \text { tahun } 2018 \\
\text { tentang Petunjuk Operasional Pengelolaan Dana Alokasi Khusus Fisik } \\
\text { Bidang Pariwisata, Bab } 5 \text { Bagian E. Pembangunan, Peningkatan / } \\
\text { Revitalisasi Sarana Pendukung Daya Tarik Wisata mengenai : } \\
\text { "Jalan utama bisa berpapasan } 2 \text { (dua) bus" } \\
\text { - Kondisi jalan di dalam Kawasan sudah cukup baik, sudah diaspal } \\
\text { - dan hampir tidak adanya jalan berlubang. } \\
\text { - Jarak dari pusat kota hanya sekitar } 2 \mathrm{~km} \text {. } \\
\text { - Memiliki banyak pintu masuk dari berbagai arah. }\end{array}$ \\
\hline & Listrik & $\begin{array}{l}\text { - Sudah terlayani listrik. } \\
\text { - Pasokan listrik di kawasan Pantai Teluk Penyu dan Benteng } \\
\text { Pendem Cilacap berasal dari PLTU Karangkandri }\end{array}$ \\
\hline & Air Bersih & $\begin{array}{l}\text { - Sumber air bersih di Pantai Teluk Penyu sebagian berasal dari air } \\
\text { PDAM dan air tanah yang berasal dari sumur bor. }\end{array}$ \\
\hline
\end{tabular}

Pada analisis ini untuk melihat bagaimana kondisi prasarana dan sarana pada kondisi eksisting berdasarkan kebijakan yang sesuai.

Tabel 1. Kesimpulan Analisis Kondisi Eksisting Sarana dan Prasana 
- Kualitas air tidak begitu baik, air tanah yang dihasilkan dari sumur bor sedikit keruh sehingga penggunaan air bersih sangat terbatas.

Kebersihan Berdasarkan Peraturan Menteri Pariwisata nomor 3 tahun 2018 tentang Petunjuk Operasional Pengelolaan Dana Alokasi Khusus Fisik Bidang Pariwisata, Bab 5 Kriteria Teknis Pelaksanaan kegiatan mengenai :

"Tempat sampah tertutup yang terdiri atas: tempat sampah organik dan tempat sampah non-organik; "

- Tempat sampah sudah dibedakan antara tempat sampah kering dan basah atau tempat sampah pilah.

- Persebaran tempat sampah yang kurang merata.

- Kurangnya kesadaran pengunjung akan kebersihan.

Jaringan - Adanya beberapa tower Base Transceiver Station (BTS) sebagai Komunikasi pendukung akses komunikasi yang baik.

Kondisi Parkir

Tersedia lahan parkir utama untuk per

- Tersedia lahan parkir utama untuk pengunjung Pantai Teluk Penyu dan Benteng Pendem.

Sarana

(Fasilitas

Umum)

- Parkir tersebar ke dalam beberapa titik.

- Kebutuhan parkir kurang mencukupi pada masa liburan

- Lahan parkir digunakan untuk umum baik kendaraan beroda empat maupun roda dua.

- Setiap lahan parkir dijaga langsung oleh petugas parkir dan biaya parkir dibayarkan langsung kepada petugas.

Toilet/Kamar Berdasarkan Peraturan Menteri Pariwisata nomor 3 tahun 2018 Mandi tentang Petunjuk Operasional Pengelolaan Dana Alokasi Khusus Fisik Bidang Pariwisata, Bab 5 Kriteria Teknis Pelaksanaan kegiatan mengenai :

"Toilet, disarankan memiliki toilet yang sesuai dengan ketentuan peraturan perundang-undangan dan dipisahkan sesuai jenis kelamin (pria dan wanita) serta pengguna (pengunjung dan pengelola)"

- Tidak adanya pemisahan toilet berdasarkan jenis kelamin maupun pengelola dan pengunjung

- Kebersihan dan penerangan pada semua toilet yang ada masih sangat kurang, karena kondisinya terkesan kumuh dan hanya dibangun secara swadaya oleh masyarakat sekitar. Masih sangat jarang toilet yang memiliki kloset.

- Beberapa pintu toilet atau kamar mandi yang ada tidak dapat dikunci dengan baik,

Pos Keamanan - Terdapat 2 pos keamanan,yaitu pos Polres Cilacap dan pos TNI AL.

- Lokasi pos keamanan strategis

- Kondisi fisik pos keamanan cukup terawat

- Tidak terdapat keamanan berupa safeguard pos pada kawasan pantai.

- Pos informasi kurang berfungsi dengan baik

Penerangan Jalan - Penerangan jalan di sepanjang jalan dalam kawasan wisata Pantai Teluk Penyu dan Benteng Pendem sudah cukup memadai.

- Beberapa lampu jalan di kawasan wisata ini juga sudah menggunakan teknologi sollar cell atau tenaga surya.

Kondisi Homestay

- Belum adanya Homestay atau penginapan di dalam Kawasan wisata 


\begin{tabular}{|c|c|c|}
\hline \multirow[t]{2}{*}{$\begin{array}{l}\text { (Fasilitas } \\
\text { Pariwisata) }\end{array}$} & Warung/Restoran & $\begin{array}{l}\text { - Kondisi warung-warung terlihat sedikit kumuh karena lokasinya } \\
\text { yang jadi satu dengan toilet atau kamar mandi umum dan hanya } \\
\text { memiliki penerangan seadanya. } \\
\text { - Kondisi restoran cukup baik dengan bangunan permanen. }\end{array}$ \\
\hline & Gazebo & $\begin{array}{l}\text { - Terdapat sekitar } 13 \text { gazebo dengan ukuran yang cukup besar, tiap } \\
\text { gazebo dapat menampung hingga } 15 \text { orang. } \\
\text { - Untuk kebersihan gazebo masih sangat kurang. } \\
\text { - Pemakaian gazebo ini tidak dipungut biaya. } \\
\text { - Dengan ukuran pantai yang cukup panjang jumlah gazebo masih } \\
\text { kurang untuk menampung wisatawan. }\end{array}$ \\
\hline
\end{tabular}

Sumber : Olahan Penulis, 2019

\section{Analisis Penerapan Rencana}

\section{Gerbang Utama}

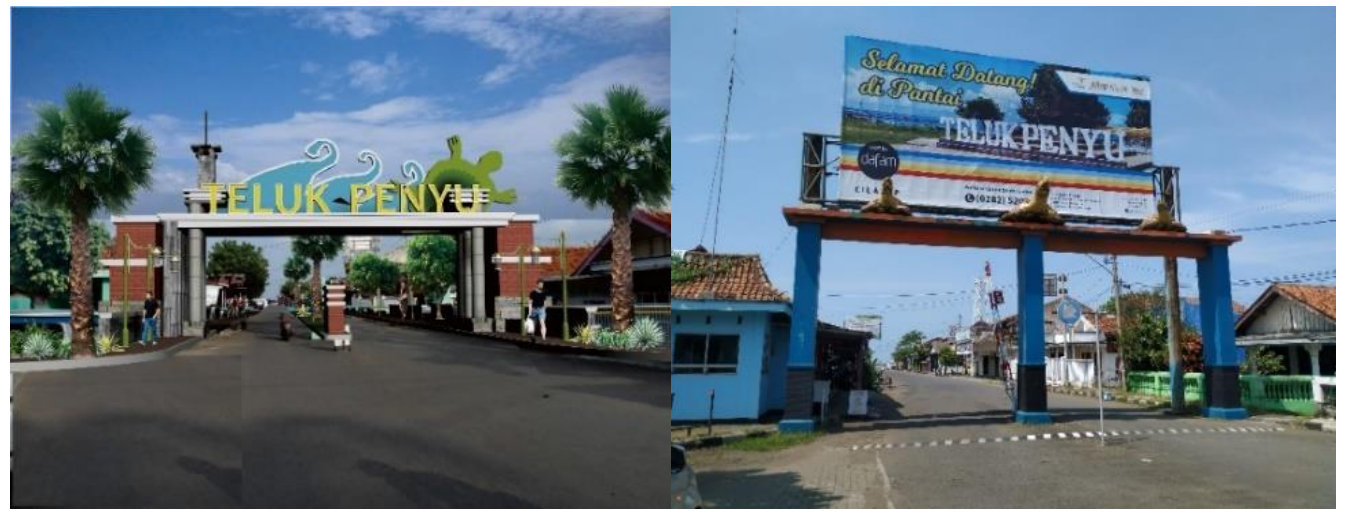

Gambar 1. Rencana Fisik dan Eksisting Gerbang Utama

Sumber: Penulis, 2019

Sudah adanya gerbang utama namun jauh berbeda dari rencana fisik yang ada dalam RTBL.

\section{Jalan Utama}
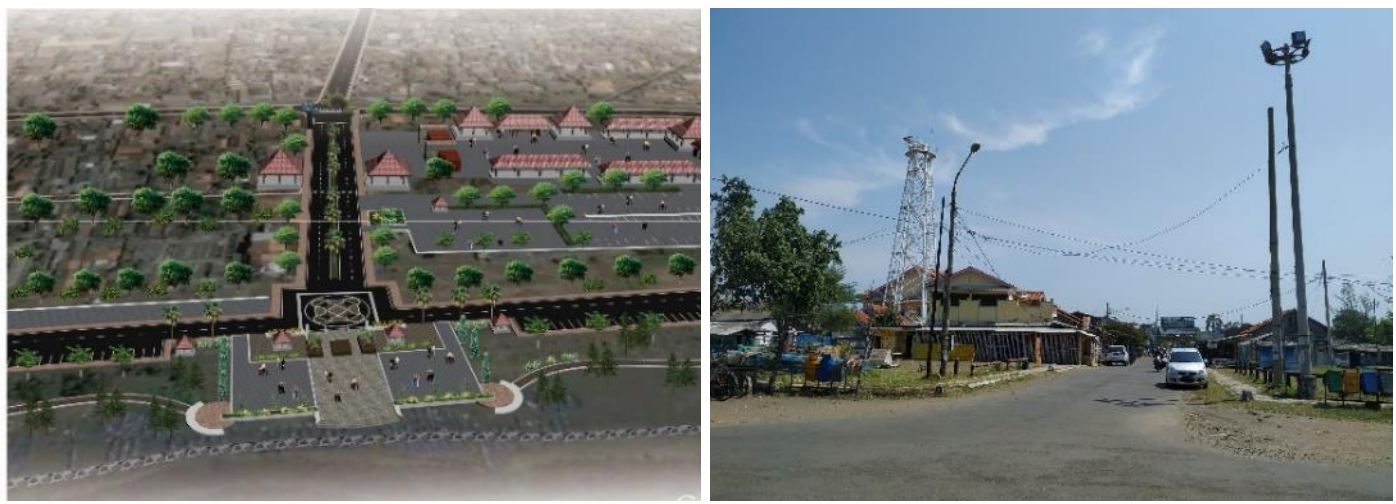

Gambar 2. Rencana Fisik dan Eksisting Jalan Utama

Sumber: Penulis, 2019

Belum ada realisasi sama sekali, baik pedestrian ataupun median jalan 


\section{Plaza}
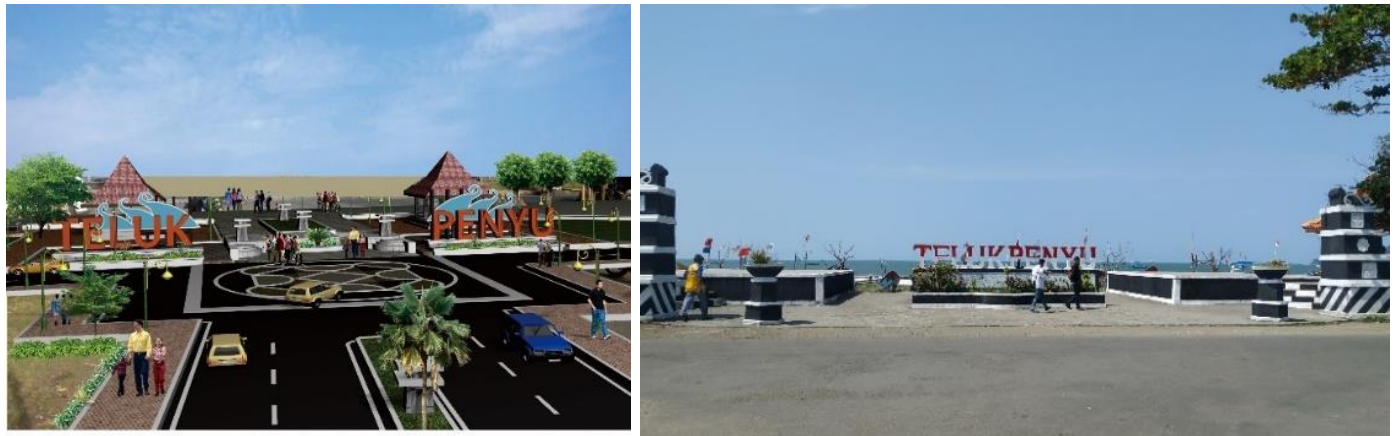

Gambar 3. Rencana Fisik dan Eksisting Plaza Teluk Penyu

Penulis, 2019

Sudah terealisasi namun tidak sesuai dengan rencana fisik pada RTBL

\section{Aquarium dan Minipool}
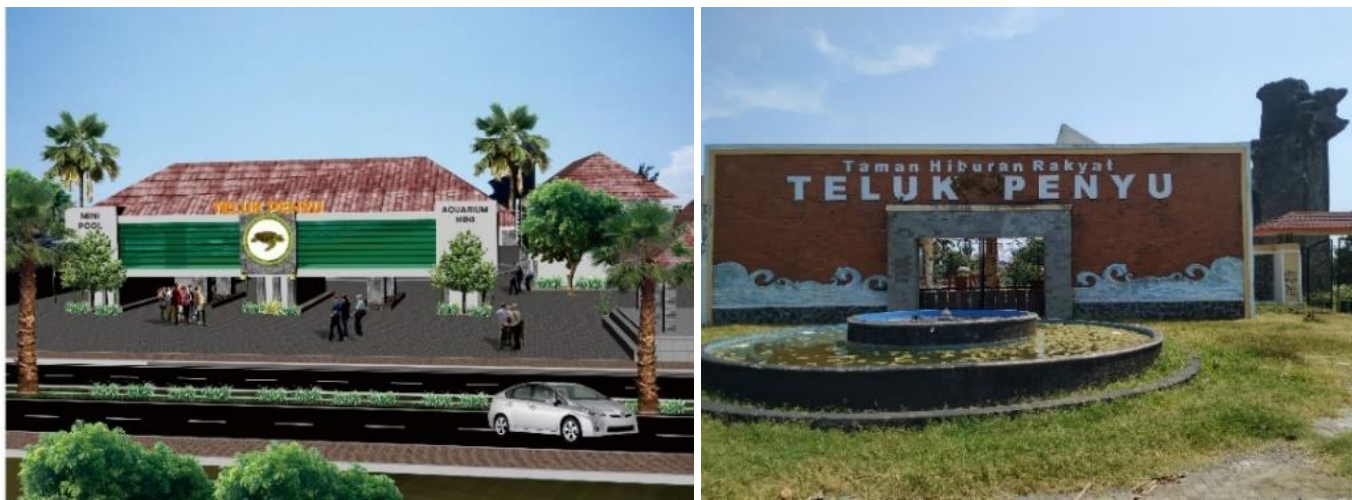

Gambar 4. Rencana Fisik dan Eksisting Aquarium dan Minipool

Penulis, 2019

Merupakan rencana penambahan fasilitas sebagai pengganti THR Teluk Penyu

5. Kawasan Benteng Pendem

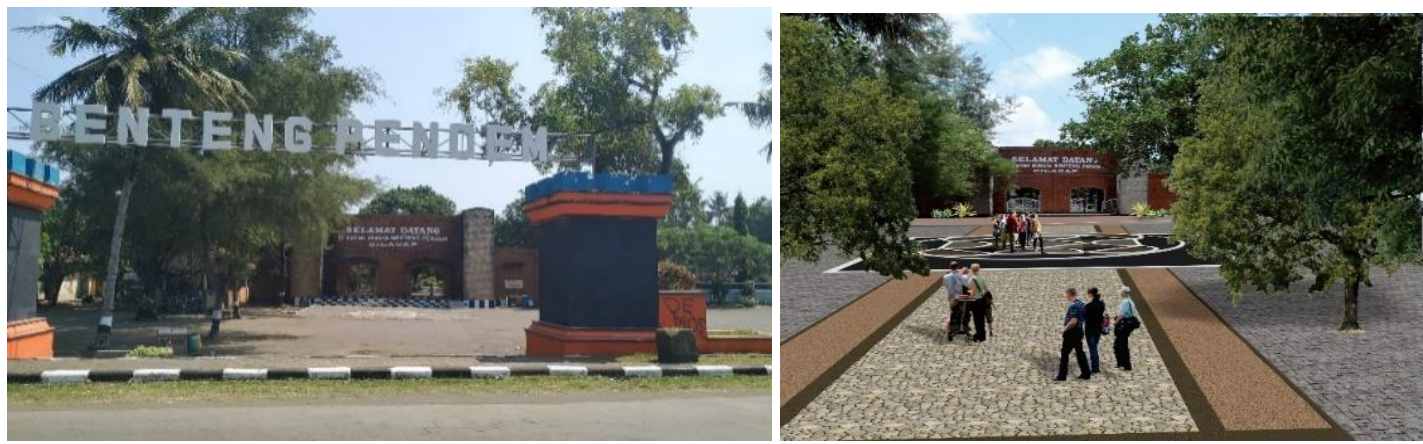

Gambar 5. Desain Lahan dan Eksisting depan kawasan Benteng Pendem

Penulis, 2019

Pada eksisting sudah sesuai rencana, yaitu lahan luas persis di depan Benteng Pendem 


\section{Pedestrian}
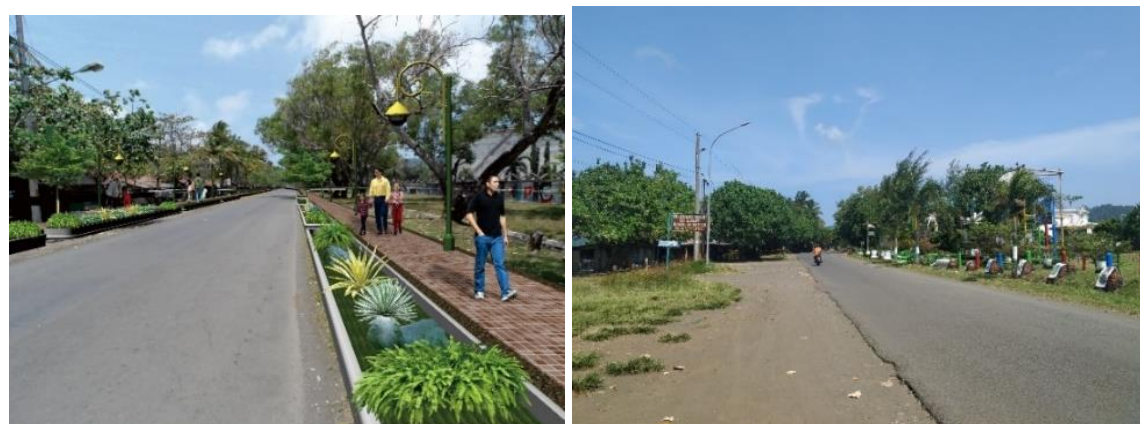

Gambar 6. Desain Pedestrian dan Kondisi jalan pada kawasan wisata

Penulis, 2019

Belum ada pedestrian sesuai rencana pada Kawasan Pantai Teluk Penyu dan Benteng Pendem

\section{Taman}
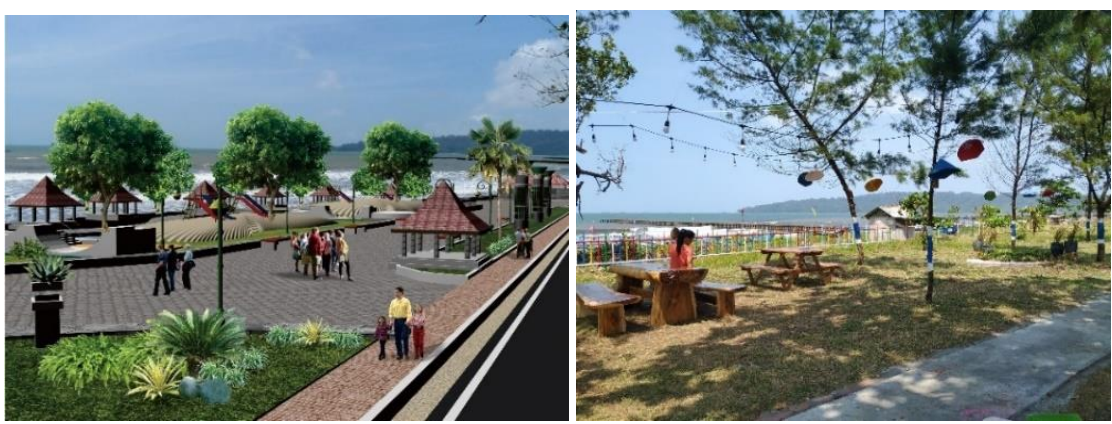

Gambar 7. Desain Taman bermain dan Kondisi jalan pada kawasan wisata Penulis, 2019

Pada RTBL terdapat rencana pembangunan taman bermain anak-anak lengkap dengan fasilitas bermainnya. Namun pada eksisting hanya ad ataman kecil disepanjang tepi pantai dengan bangkubangku taman

\section{Cafetaria}

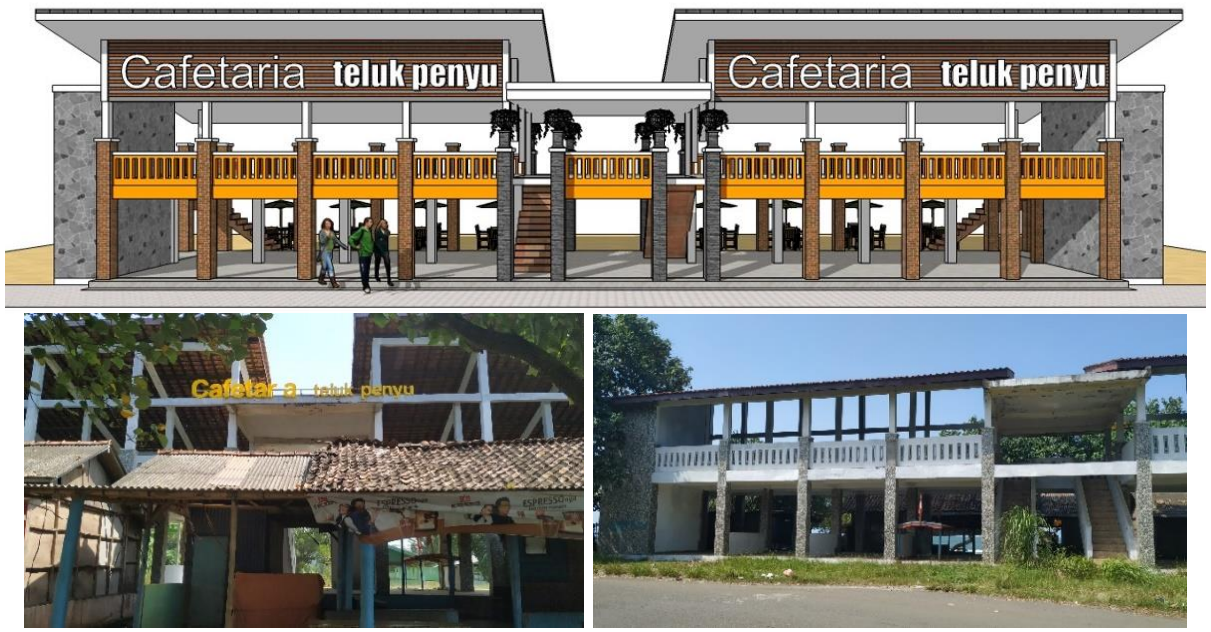

Gambar 8. Desain Cafetaria dan Eksisting Cafetaria

Penulis, 2019 
Sudah terbangun sesuai rencana dalam RTBL namun tidak sesuai dengan keinginan masyarakat sehingga tidak gunakan dan tidak berfungsi dengan baik

\section{Analisis Kebijakan}

Peraturan Menteri Pekerjaan Umum nomor 6 tahun 2007 tentang Pedoman Umum Rencana Tata Bangunan dan Lingkungan (RTBL)

Faktor berdasarkan Aspek Tata Bangunan :

a. Optimalisasi dan efisiensi

- Penentuan desain kaveling/blok yang paling optimal dan efisien bagi lingkungan secara spesifik dan khas, terkait dengan pemenuhan aspek-aspek fungsional, visual, dan kualitas lingkungan;
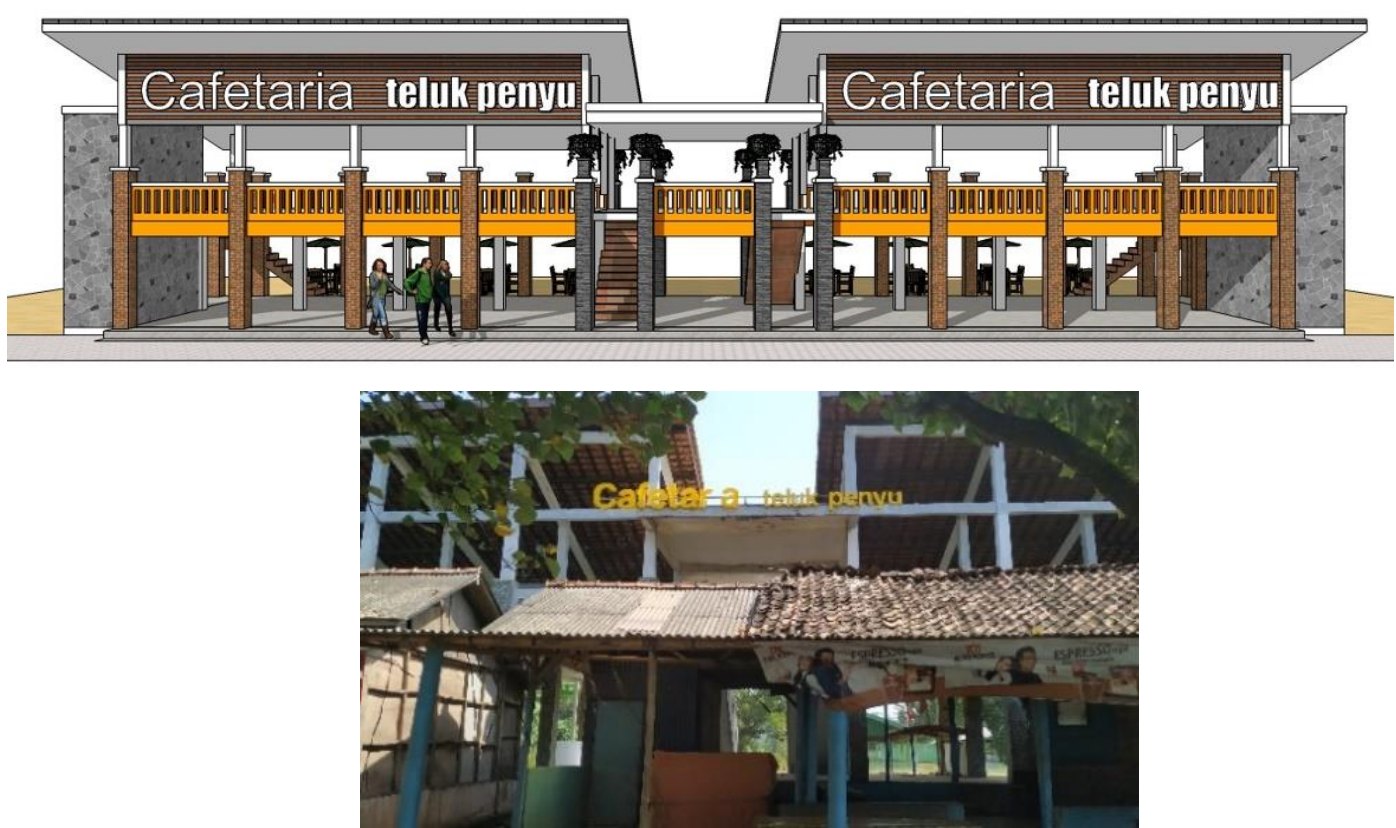

Gambar 9. Rencana Fisik dan Eksisting Cafetaria sesuai RTBL

Penulis, 2019

Hal ini tidak selaras dengan dibangunnya cafeteria pada kawasan pantai. Dikarenakan kondisi cafeteria yang kecil hanya dengan lebar sekitar $2 \times 2 \mathrm{~m}$ dan terbangun dengan 2 lantai, para pedagang mengeluhkan luas perkios yang kecil, dan harus membawa barang dagangannya ke lantai 2.

b. Skala dan proporsi ruang yang berorientasi pada pejalan kaki

- Penciptaan keseimbangan tata bangunan yang berorientasi pada "ramah pejalan kaki", sekaligus menghidupkan ruang wilayah dengan berbagai aktivitas pada tingkat lingkungan pejalan kaki;

- Skala dan proporsi harus mempertimbangkan aspek visual dari skala manusiawi yang tercipta pada pejalan kaki;

Pada kondisi eksistingnya daerah ini memiliki cukup wilayah juga untuk dibangun pedestrian. Rencana pembangunan pedestrian ini sesuai dengan faktor pada Pedoman RTBL dan kesesuaian kondisi eksisting. 


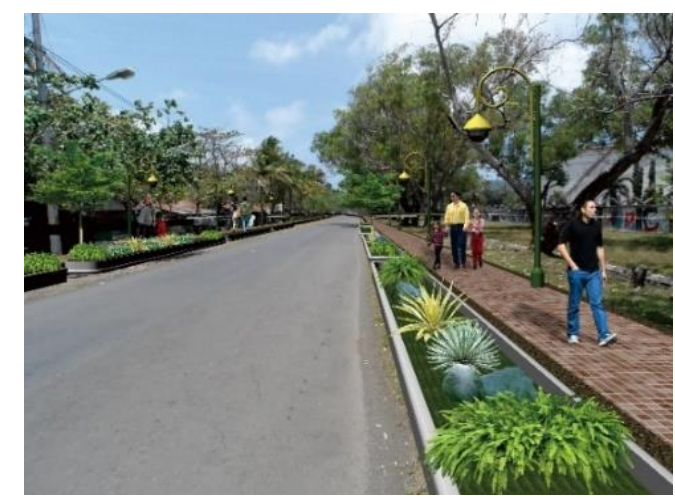

Gambar 10. Rencana Fisik Pedestrian pada RTBL

Sumber : Dinas PUPR, 2019

c. Ekspresi bangunan dan lingkungan

- Penetapan panduan ekspresi arsitektur yang memperkaya dan mengembangkan arsitektur khas Indonesia;

- Penciptaan ruang wilayah/lingkungan yang bermakna dan terkait dengan jati diri setempat, tidak bersifat figuratif, serta berkorelasi dengan kultur perilaku/budaya, nilai-nilai historis dan kehidupan khas setempat;

- Penetapan panduan jenis langgam/gaya bangunan yang mengacu pada kontekstualitas lingkungan sekitar, terutama yang memang sudah memiliki langgam tertentu atau pun pada daerah yang dipugar;

Pada kawasan wisata terdapat beberapa peninggalan sejarah seperti mercusuar dan wisata Benteng Pendem. Pada seluruh bangunan peninggalan ini dipertahankan bentuk keaslian dari peninggalan. Namun untuk kawasan Benteng Pendem, bagian depan atau loket merupakan penambahan atau bangunan baru, namun tidak menghilangkan ciri khas Benteng Pendem sebagai peninggalan bekas benteng pertahanan. Di dalam kawasan Benteng Pendem sebagian juga sudah diperbarui atau ditambah beberapa taman untuk menunjang wisata.
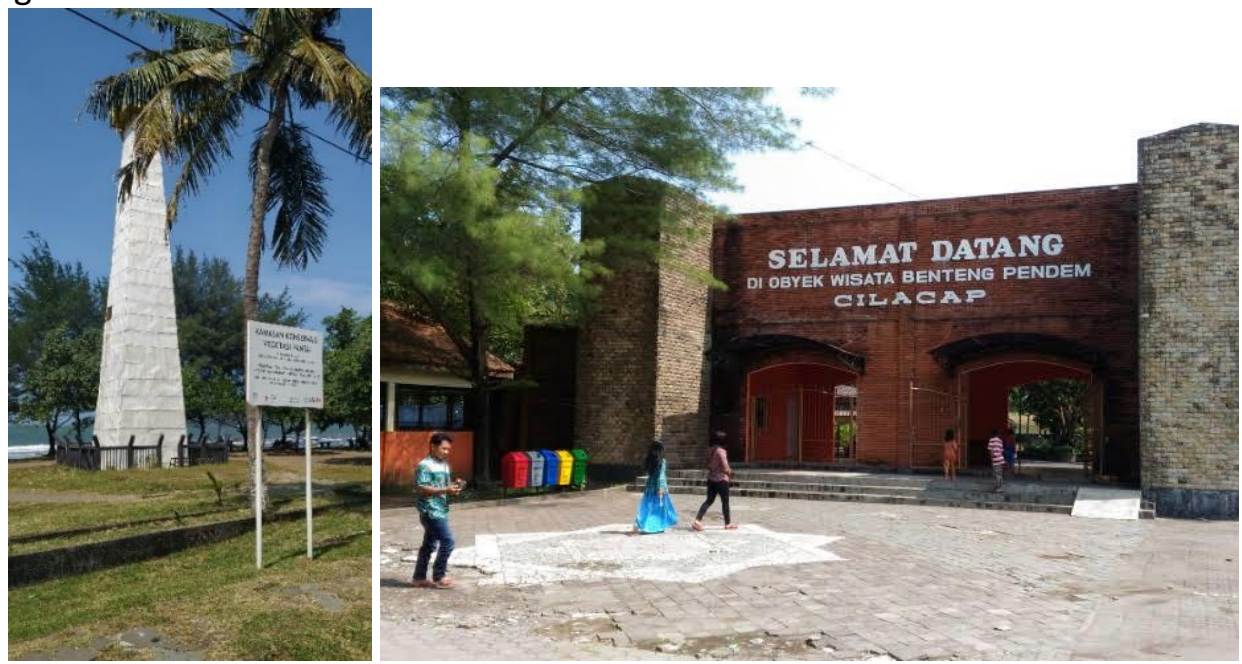

Gambar 11. Keaslian peninggalan sejarah di kawasan Benteng Pendem

Penulis, 2019 
d. Pemberdayaan kawasan Peningkatan modifikasi desain/pengembangan yang sesuai dengan karakter lokal.

Adapun peningkatan modifikasi desain dari kondisi eksisting yaitu bekas kolam renang Taman Hiburan Rakyat (THR) menjadi minipool.

Rencana Penambahan fasilitas minipool yang dijadikan satu dengan Aquarium untuk edukasi anak. Pada kondisi eksisting, atau lahan yang akan dibuat rencana juga sudah terbangun bekas kolam renang yang cukup besar namun pada saat pengelolaan kolam renang tidak diteruskan dikarenakan tidak adanya untung dari dibukanya fasilitas wisata kolam renang. Rencana fasilitas ini dapat dikatakan sesuai dengan Pedoman RTBL, namun tidak sesuai dengan kebutuhan kawasan.
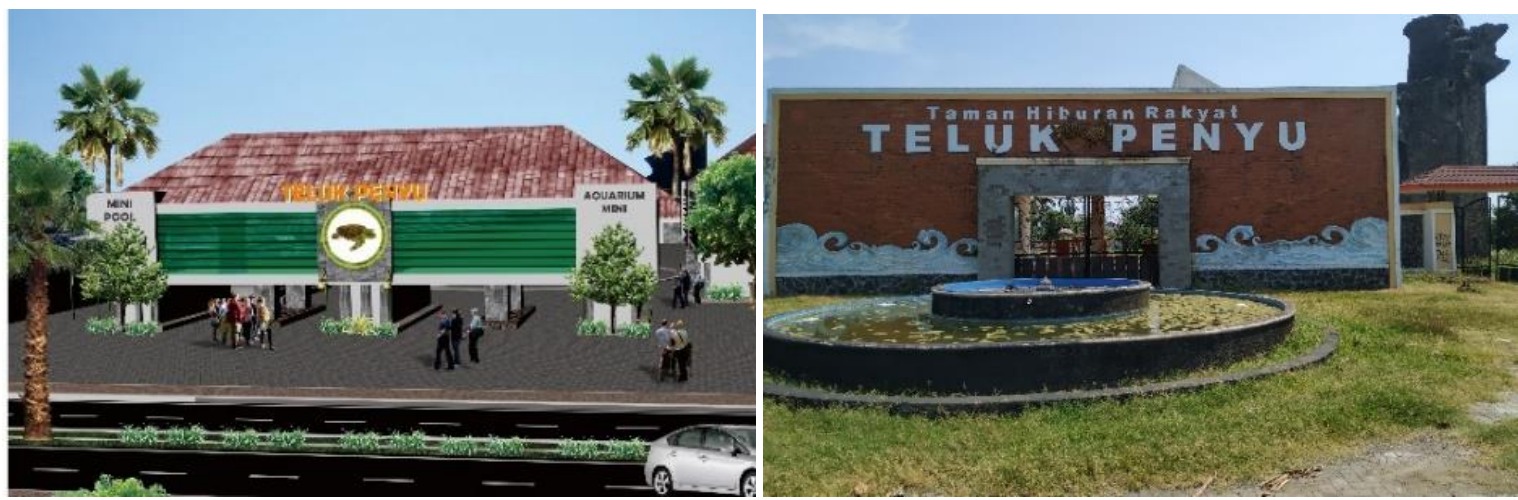

Gambar 12. Peningkatan Desain Bangunan Kolam renang

Penulis, 2019

\section{Faktor berdasarkan Aspek Kualitas Lingkungan :}

a. Skala dan proporsi pembentukan ruang yang berorientasi pada pejalan kaki Penciptaan keseimbangan lingkungan fisik yang lebih berorientasi pada pejalan kaki daripada kendaraan, sehingga tercipta lingkungan yang ramah bagi pejalan kaki seraya menghidupkan ruang kota melalui berbagai aktivitas pada area pejalan kaki.

Pada kawasan wisata Pantai Teluk Penyu belum menguatamakan orientasi pada pejalan kaki, dilihat dari belum adanya trotoar untuk pejalan kaki dan lebih mementingkan kendaraan karena panjang pantai yang cukup jauh juga untuk dicapai dengan jalan kaki.

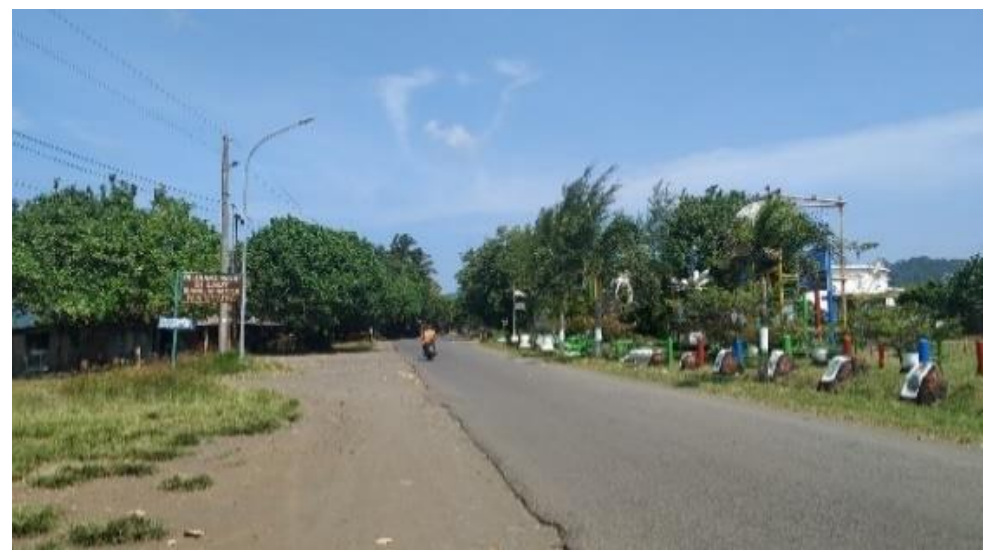

Gambar 13. Eksisting Kondisi Jalan tanpa trotoar

Penulis, 2019 
b. Perencanaan tepat bagi pemakai yang tepat Perencanaan penanda informasi/orientasi visual yang jelas dan tepat peletakannya, dan diperuntukkan bagi jenis pengguna yang tepat juga, yaitu antara pejalan kaki, pengendara sepeda dan pengendara kendaraan bermotor.

Pada kondisi eksistingnya lahan-lahan parkir yang sudah tersedia jarang digunakan dengan semestinya. Bahkan para wisatawan lebih memilih parkir di tepi pantai dengan kondisi yang tidak tertata antara kendaraan roda dua dan roda empat.
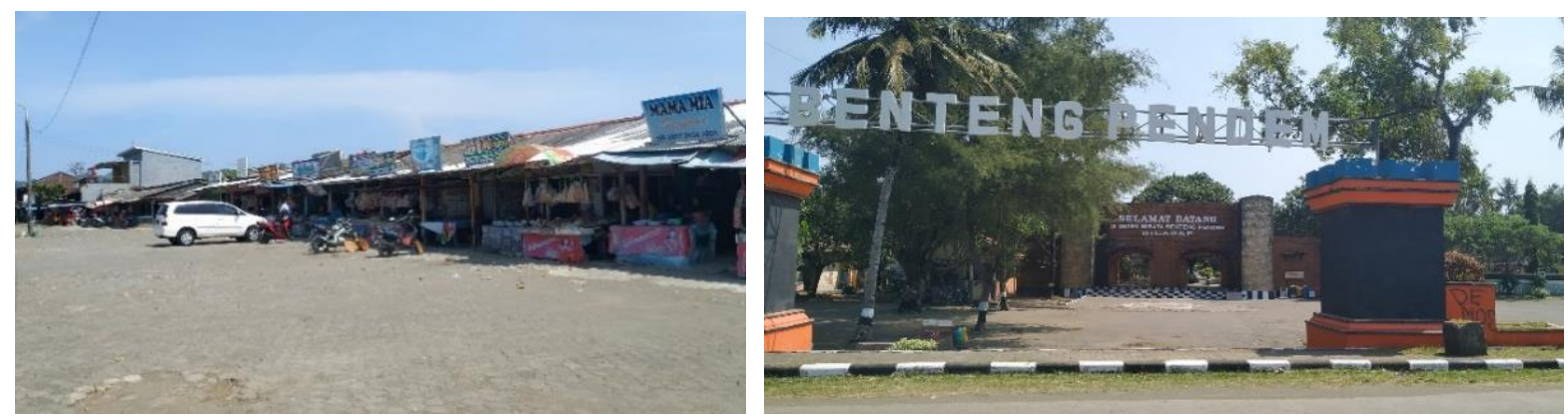

Gambar 14. Kondisi Lahan Parkir Pantai Teluk Penyu dan Benteng Pendem Penulis, 2019

c. Kelengkapan fasilitas penunjang lingkungan Penyediaan elemen pendukung kegiatan seperti street furniture (kios, tempat duduk, lampu, material perkerasan, dan lain-lain).

Adapun penambahan fasilitas penunjang taman bermain ini sesuai dengan faktor tersebut sebagai fasilitas penunjang.

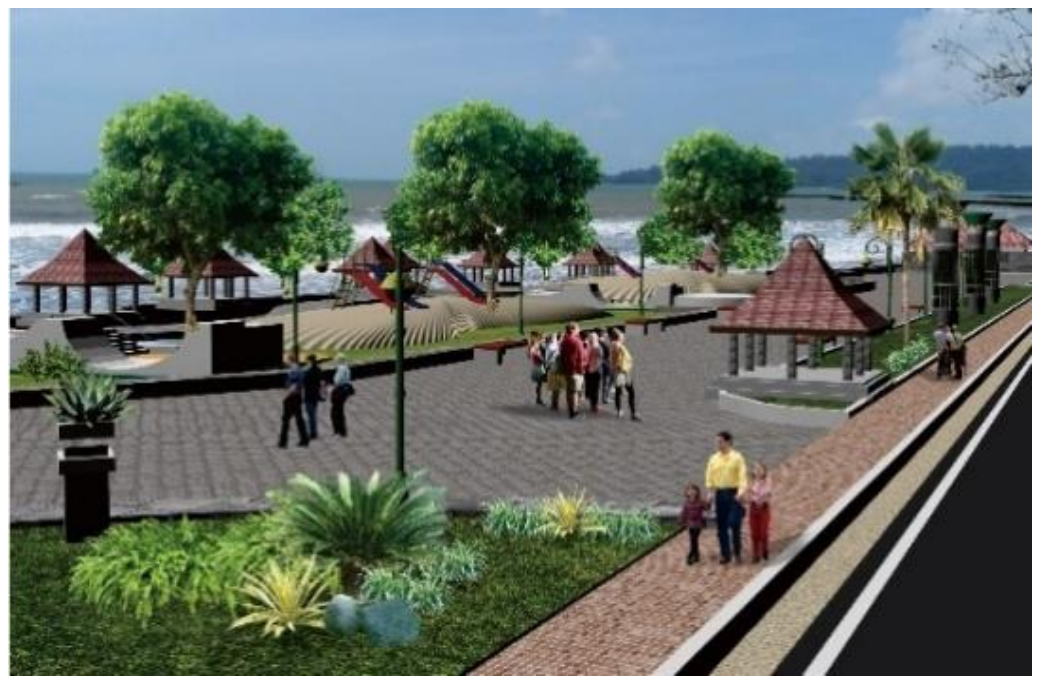

Gambar 15. Rencana Fisik Taman bermain anak pada RTBL Sumber : Dinas PUPR, 2019

\section{Analisis Persepsi dan Preferensi}

\section{Persepsi}

Apabila nilai kesesuaian masing-masing atribut melebihi nilai kesesuaian rata-ratanya maka dapat dikatakan pelanggan puas, tetapi apabila berada dibawah nilai kesesuaian rata-ratanya maka dianggap perlu ditingkatkan. (supratno: 2001). 


\begin{tabular}{|c|c|c|c|c|}
\hline Aspek & $\begin{array}{c}\text { Tingkat Kinerja } \\
(\mathrm{Xi})\end{array}$ & $\begin{array}{c}\text { Tingkat } \\
\text { Kepentingan (Yi) }\end{array}$ & $\begin{array}{c}\text { Tingkat } \\
\text { Kesesuaian (TKi) }\end{array}$ & Keterangan \\
\hline Jaringan Jalan & 296 & 402 & 73.6 & Perlu di Tingkatkan \\
\hline Penerangan Jalan & 291 & 424 & 68.6 & Perlu di Tingkatkan \\
\hline Kebersihan/Tempat Sampah & 254 & 450 & 56.4 & Perlu di Tingkatkan \\
\hline Pintu masuk/Loket Tiket & 316 & 385 & 82.1 & Pertahankan \\
\hline Pusat Informasi & 301 & 411 & 73.2 & Perlu di Tingkatkan \\
\hline Pos Keamanan & 321 & 419 & 76.6 & Pertahankan \\
\hline Fasilitas Pejalan Kaki & 307 & 397 & 77.3 & Pertahankan \\
\hline Lahan Parkir & 328 & 426 & 77.0 & Pertahankan \\
\hline Toilet/Kamar Mandi Umum & 299 & 451 & 66.3 & Perlu di Tingkatkan \\
\hline Warung/Restoran & 350 & 410 & 85.4 & Pertahankan \\
\hline Kios Souvenir & 336 & 396 & 84.8 & Pertahankan \\
\hline Gazebo & 314 & 413 & 76.0 & Pertahankan \\
\hline Total & 3713 & 4984 & 897.5 & \\
\hline Rata-rata & 309.4 & 415.3 & 74.8 & \\
\hline
\end{tabular}

Sumber : Olahan Penulis, 2019

\section{Preferensi}

a. Kegiatan/fasilitas Wisata yang Perlu Diadakan

Berikut merupakan hasil penjumlahan skor untuk kegiatan wisata yang perlu ditambahkan di Pantai Teluk Penyu dan Benteng Pendem yang dipilih oleh responden, yaitu:

Tabel 3. Fasilitas Wisata yang perlu diadakan

\begin{tabular}{lcc}
\hline \multicolumn{1}{c}{ Jenis Kegiatan } & Total Skor & Peringkat \\
\hline Cafetaria & 22 & 4 \\
\hline Taman bermain anak & 41 & 2 \\
\hline Mini Pool/Kolam renang & 9 & 6 \\
\hline Wisata Edukasi & 44 & 1 \\
\hline Penginapan & 16 & 5 \\
\hline Gazebo & 24 & 3
\end{tabular}

Sumber : Olahan Penulis, 2019

b. Fasilitas umum yang Perlu Ditambahkan

Berikut merupakan hasil penjumlahan skor untuk fasilitas yang perlu ditambahkan di Pantai Teluk Penyu dan Benteng Pendem yang dipilih oleh responden, yaitu:

Tabel 4. Fasilitas Umum yang perlu diadakan

\begin{tabular}{lcc}
\hline Jenis Fasilitas & Total Skor & Peringkat \\
\hline Lahan Parkir & 23 & 4 \\
\hline Pedestrian & 30 & 2 \\
\hline Pusat Informasi & 44 & 1 \\
\hline Toilet/Kamar Mandi Umum & 27 & 3
\end{tabular}

Sumber : Olahan Penulis, 2019 


\section{KESIMPULAN DAN SARAN}

\section{Kesimpulan}

Terdapat kesesuain sebagian rencana pada RTBL Pantai Teluk Penyu dan Benteng Pendem. Namun pada RTBL tidak seluruhnya memenuhi kesesuaian berdasarkan fakto-faktor pedoman umum RTBL. Rencana fisik yang sesuai dengan faktor-faktor pedoman umum adalah berupa rencana pembangunan pedestrian, namun sayangnya hal ini merupakan prioritas rendah berdasarkan kuesioner yang sudah diisi oleh para pengunjung.

Kemudian yang kedua ada rencana pembangunan taman bermain yang sesuai dengan faktor fisik dan non-fisik pada aspek kualitas lingkungan. Lalu sebagian penerapan yang tidak sesuai dengan faktor-faktor pedoman umum RTBL adalah dibangunnya cafeteria yang juga pembangunannya tidak sesuai dengan kebutuhan pedagang sekitar, dan pembangunan mini pool yang sebelumnya sudah terbangun kolam renang besar namun tidak beroperasi lagi. Beberapa rencana yang tidak sesuai dengan faktor-faktor pedoman umum RTBL ataupun fungsinya untuk selanjutnya dapat disesuaikan dengan faktor-faktor yang ada dan kondisi eksisting kawasan wisata.

\section{Saran}

Adapun saran yang akan diberikan penulis untuk pengelola agar rencana kawasan kedepannya adalah:

a. Penambahan fasilitas pusat informasi agar memudahkan para pengunjung jika ada sesuatu hal yang ingin ditanyakan mengenai kawasan dan fasilitasnya, juga jika sewaktu-waktu terjadi hal tidak terduga terkait wisatawan dapat mengerti akan bertanya kepada siapa

b. Tidak membangun fasilitas yang sudah pernah dijalankan namun akhirnya terbengkalai atau tidak menguntungkan pengelola.

c. Mengajak masyarakat setempat untuk berdiskusi terkait rencana kawasan yang akan dibuat, sehingga tidak terjadi lagi bangunan yang didirikan namun mangkrak karna tidak sesuai dengan kebutuhan.

d. Menambah fasilitas-fasilitas wisata yang ramah anak.

\section{REFERENSI}

Jones, C. O., (2009) An Introduction to the Study of Public Policy

Kotaku, (2016). Uraian Singkat Penyusunan Rencana Tata Bangunan dan Lingkungan (RTBL), diakses pada 28 Mei 2019, <http://kotakupu.blogspot.com./2016/11/uraian-singkatpenyusunan-rencana-tata.html

Peraturan Menteri Pekerjaan Umum (2007), Peraturan Menteri Pekerjaan Umum nomor 6 tahun 2007 tentang Pedoman Umum RTBL. Jakarta

Peraturan Pemerintah, (2006), Peraturan Pemerintah Nomor 39 tahun 2006 tentang Tata Cara Pengendalian dan Evaluasi Pelaksanaan Rencana Pembangunan. Jakarta.

Pusat Bahasa Depdiknas, (2002). Kamus Besar Bahasa Indonesia. Jakarta : Balai Pustaka 